\title{
PENERAPAN MODEL PEMBELAJARAN GROUP INVESTIGATION (GI) UNTUK MENINGKATKAN KEMAMPUAN BERPIKIR KRITIS SISWA KELAS X SMA NEGERI 2 DELIMA
}

\author{
Junaidi $^{(1)}$, Taufiq ${ }^{(2)}$ \\ ${ }^{1,2}$ Program Studi Pendidikan Matematika FKIP Universitas Jabal Ghafur Sigli \\ Email : taufiq@unigha.ac.id
}

\begin{abstract}
ABSTRAK
Penelitian ini tentang penerapan model pembelajaran Group Investigation (GI) untuk meningkatkan kemampuan berpikir kritis siswa kelas X SMA Negeri 2 Delima. Penelitian ini bertujuan untuk meningkatkan kemampuan berpikir kritis siswa yang diajarkan dengan model pembelajaran Group Investigation (GI). Adapun yang menjadi populasi dalam penelitian ini adalah seluruh siswa kelas X SMA Negeri 2 Delima yang terdiri atas 4 kelas dengan jumlah 110 siswa yang terdiri atas 36 laki-laki dan 74 perempuan. Sampel untuk penelitian ini adalah siswa kelas X MIPA 2 sebagai kelas eksperimen dan kelas X MIPA ${ }_{1}$ sebagai kelas kontrol. Jenis penelitian yang digunakan adalah penelitian kuasi eksperimen. Pengumpulan data dilakukan dengan tes awal dan tes akhir, dan pengolahan data menggunakan uji-t. Hasil analisis data menunjukkan bahwa berdasarkan uji terhadap hipotesis penelitian bahwa nilai Uji-t diperoleh $t_{\text {hitung }}=3,52$ dengan nilai signifikan $0,000<\alpha=0,05$, maka dapat diambil kesimpulan bahwa peningkatan kemampuan berpikir kritis siswa yang diajarkan dengan model pembelajaran Group Investigation (GI) lebih baik daripada peningkatan kemampuan berpikir kritis siswa yang diajarkan dengan model konvensional.
\end{abstract}

Kata Kunci: Group Investigation (GI), Kemampuan Berpikir Kritis.

\section{PENDAHULUAN}

Model pembelajaran kooperatif merupakan model pembelajaran dengan menggunakan kelompok kecil yang terdiri dari beberapa siswa yang dikelompokkan secara heterogen dan saling bekerjasama dalam memecahkan masalah. Setiap siswa yang ada dalam kelompok mempunyai tingkat kemampuan yang berbeda-beda (tinggi, sedang dan rendah) dan jika memungkinkan anggota kelompok berasal dari ras, budaya, suku yang berbeda serta memperhatikan kesetaraan gender. Model pembelajaran kooperatif mengutamakan kerjasama dalam menyelesaikan masalah untuk menerapkan pengetahuan dan keterampilan dalam rangka mencapai tujuan pembelajaran. Tujuan model pembelajaran kooperatif adalah hasil belajar akademik siswa meningkat dan siswa dapat menerima berbagai keragaman dari temannya, serta pengembangan keterampilan sosial, Daryanto dan Raharjo (2012:242).

Salah satu tipe model pembelajaran kooperatif yaitu group investigation. Model pembelajaran kooperatif tipe group investigation yaitu pembelajaran dengan cara diskusi kelompok dan dilakukan investigasi pada diskusi setiap kelompok tersebut. Group investigation merupakan model pembelajaran kooperatif yang paling kompleks dan paling sulit untuk diterapkan. Model ini dikembangkan pertama kali oleh Thelan, dalam perkembangannya model ini diperluas dan dipertajam oleh Sharan dari Universitas Tel Aviv. 
Group investigation memiliki akar filosofis, etis, psikologi penulisan sejak awal tahun abad ini. Tokoh yang paling terkemuka dari orientasi pendidikan ini adalah John Dewey. Pandangan Dewey terhadap kooperasi di dalam kelas sebagai sebuah prasyarat untuk bisa menghadapi berbagai masalah kehidupan yang kompleks. Kelompok dijadikan sebagai sarana sosial dalam proses pembelajaran di kelas. Sehingga group investigation tidak dapat diimpelmentasikan dalam lingkungan pendidikan yang dialog intrapersonalnya tidak mendukung atau rasa sosial yang kurang, Slavin (2005:214).

Menurut Wena (2013: 195) Pembentukan kelompok dalam model pembelajaran ini didasari atas minat anggotanya. Pembelajaran dengan metode group investigation menuntut melibatkan siswa sejak perencanaan, baik dalam menentukan topik maupun cara untuk mempelajari melalui investigasi. Tujuan dari tipe group investigation ini yaitu untuk meningkatkan kemampuan kreativitas dapat ditempuh melalui pengembangan proses kreatif menuju suatu kesadaran dan pengembangan alat-alat bantu yang secara eksplisit mendukung kreativitas dan meningkatkan peluang keberhasilan dalam memecahkan suatu masalah harus terlebih dahulu memahami konsep emosional dan non emosional. Model pembelajaran kooperatif tipe group investigation memiliki seperangkat komponen pembentuk kegiatan pembelajaran, yaitu tujuan, materi, kegiatan implementasi dan evaluasi, Daryanto, Muljo Rahardjo (2012:233).

Setiawan (2006: 9) mengemukakan beberapa kelebihan dari pembelajaran Group Investigation (GI), yaitu :

- Dalam proses belajarnya siswa dapat bekerja secara bebas sesuai dengan topik pembelajaran yang diberikan
- Memberi semangat untuk berinisiatif, kreatif, dan aktif selama proses diskusi berlangsung

- Rasa percaya diri dapat lebih meningkat

- Meningkatkan belajar bekerja sama

- Belajar berkomunikasi baik dengan teman sendiri maupun guru

- Belajar menghargai pendapat orang lain

- Meningkatkan partisipasi dalam membuat suatu keputusan

- Siswa terlatih untuk mempertanggungjawabkan jawaban yang diberikan

- Mengembangkan dan melatih keterampilan dalam berbagai bidang

- Merencanakan dan mengorganisasikan pekerjaannya

- Dapat mengecek kebenaran jawaban yang mereka buat

- Selalu berfikir tentang cara atau strategi yang digunakan sehingga didapat suatu kesimpulan yang berlaku umum.

Menurut Setiawan (2006:9), model pembelajaran Group Investigation (GI) selain memiliki kelebihan juga terdapat beberapa kekurangannya, yaitu:

- Sedikitnya materi yang tersampaikan pada satu kali pertemuan,

- Sulitnya memberikan penilaian secara personal,

- Tidak semua topik cocok dengan model pembelajaran GI, model pembelajaran GI cocok untuk diterapkan pada suatu topik yang menuntut siswa untuk memahami suatu bahasan dari pengalaman yang dialami sendiri,

- Diskusi kelompok biasanya berjalan kurang efektif,

- Siswa yang tidak tuntas memahami materi prasyarat akan mengalami kesulitan saat menggunakan model ini.

Berdasarkan pemaparan mengenai model pembelajaran Group Investigation (GI) tersebut, jelas bahwa model pembelajaran Group Investigation (GI) mendorong siswa untuk belajar lebih aktif 
Jurnal Sosial Humaniora Sigli (JSH)

p ISSN : 2615-3688

$e$ ISSN : 2716-0270

http://journal.unigha.ac.id/index.php/JSH

dan lebih bermakna. Artinya siswa dituntut selalu berfikir tentang suatu persoalan dan mereka mencari sendiri cara penyelesaiannya. Dengan demikian mereka akan lebih terlatih untuk selalu menggunakan keterampilan pengetahuannya, sehingga pengetahuan dan pengalaman belajar mereka akan tertanam untuk jangka waktu yang cukup lama (Setiawan, 2006:9).

Menurut Steven (Sumarmo, 2011) memberikan definisi berfikir kritis sebagai berpikir dengan benar untuk memperoleh pengetahuan yang relevan dan reliabel. Berpikir kritis merupakan berpikir menggunakan penalaran, berpikir reflektif, bertanggung jawab, dan expert dalam berpikir (Rochaminah, 2008:22). Berdasarkan pengertian tersebut maka seseorang dikatakan berpikir kritis apabila dapat memperoleh suatu pengetahuan dengan cara hati-hati, tidak mudah menerima pendapat tetapi mempertimbangkan menggunakan penalaran, sehingga kesimpulannya terpercaya dan dapat dipertanggungjawabkan. Selanjutnya Steven mengemukakan bahwa proses berpikir kritis dapat digambarkan seperti metode ilmiah, yaitu: mengidentifikasi masalah, merumuskan hipotesis, mencari dan mengumpulkan data yang relevan, menguji hipotesis secara logis, melakukan evaluasi dan membuat kesimpulan yang reliabel.

Pengertian berpikir kritis menurut Krulik dan Rudnik, (Rochaminah, 2008: 22) adalah mengelompokkan, mengorganisasi, mengingat, dan menganalisis informasi yang diperlukan, menguji, menghubungkan dan mengevaluasi semua aspek dari situasi masalah. Pengertian berpikir kritis yang dikemukakan Krulik dan Rudnik pada hakekatnya sejalan dengan pengertian berpikir kritis menurut Steven karena keduanya menggunakan langkah-langkah metode ilmiah dalam melakukan proses berfikir.
Menurut Ennis (Sumarmo, 2011) mendefinisikan berpikir kritis sebagai suatu proses berpikir dengan tujuan untuk membuat keputusan-keputusan yang dapat dipertanggungjawabkan mengenai apa yang akan diyakini dan apa yang akan dilakukan. Dalam memutuskan apa yang akan dipercaya dan apa yang akan dilakukan, diperlukan informasi yang reliabel dan pemahaman terhadap topik atau lapangan studi. Berdasarkan semua hal tersebut seseorang dapat mengambil keputusan yang reliabel. Keputusan mengenai keyakinan sangat penting, Suatu kunci dalam memutuskan suatu keyakinan sering merupakan sebuah argumen. Berdasarkan definisi Ennis maka seseorang yang berpikir kritis mampu mengambil keputusan mengenai apa yang akan diyakini dan apa yang akan dilakukan berdasarkan informasi yang dapat dipercaya dan pemahaman terhadap topik yang dihadapi.

Berdasarkan definisi-definisi yang dikemukakan para ahli di atas, terdapat satu kesamaan mengenai pengertian berpikir kritis, yaitu aktivitas mental yang dilakukan menggunakan langkah-langkah dalam metode ilmiah, yaitu: memahami dan merumuskan masalah, mengumpulkan dan menganalisis informasi yang diperlukan dan dapat dipercaya, merumuskan praduga dan hipotesis, menguji hipotesis secara logis, mengambil kesimpulan secara hati-hati, melakukan evaluasi dan memutuskan sesuatu yang akan diyakini atau sesuatu yang akan dilakukan, serta meramalkan konsekuensi yang mungkin terjadi. Berpikir kritis matematis artinya berpikir kritis dalam bidang matematika.

Dari definisi berpikir kritis di atas, maka berpikir kritis matematis adalah aktivitas mental yang dilakukan menggunakan langkah-langkah sebagai berikut:

- Memahami dan merumuskan masalah dalam matematika 
- Mengumpulkan informasi yang diperlukan yang dapat dipercaya

- Merumuskan konjektur (dugaan) atau hipotesis

- Menganalisis informasi yang diperlukan dengan mengklarifikasi informasi yang diperlukan dan yang tidak diperlukan.

- Membuktikan konjektur atau menguji hipotesis dengan kaidah logika

- Menarik kesimpulan secara hati-hati (reflektif)

- Melakukan evaluasi

- Mengambil keputusan

- Melakukan estimasi dan generalisasi.

Adapun indikator kemampuan berpikir kritis siswa yang digunakan dalam penelitian ini adalah indikator kemampuan berpikir kritis dari Sumarmo (2011) yaitu:

- Kemampuan mengidentifikasi, yaitu kemampuan menjelaskan keterkaitan antar konsep, dan mengaplikasikan konsep atau algoritma secara luwes, akurat, efisien, dan tepat dalam pemecahan masalah,

- Kemampuan menggeneralisasi, yaitu kemampuan melakukan manipulasi matematika dalam membuat generalisasi, menyusun bukti atau menjelaskan gagasan dan pernyataan matematika.

- Kemampuan menganalisis algoritma, mengidentifikasi dan menyimpulkan hubungan antara pernyataan, pertanyaan, konsep, deskripsi atau bentuk-bentuk representasi lain.

- Kemampuan memecahkan masalah, yaitu kemampuan memahami masalah, merancang model matematika, menyelesaikan model dan menafsirkan solusi yang diperoleh.

\section{METODE}

Penelitian ini merupakan penelitian kuasi eksperimen dengan pendekatan kuantitatif. Dalam desain ini terdapat dua kelompok yang dipilih secara purposive sampling, yaitu pemilihan sampel dengan pertimbangan kesesuaian antara materi penelitian dengan tingkat kelas yang diteliti. Kedua kelas diberi pretes untuk mengetahui kemampuan awal siswa adakah perbedaan antara kelompok eksperimen dan kelompok kontrol. Hasil pretes yang baik bila nilai kedua kelas tidak berbeda secara signifikan (Sugiyono, 2009:113). Populasi adalah wilayah generalisasi yang terdiri atas objek/subyek yang mempunyai kualitas dan karakteristik tertentu yang ditetapkan oleh peneliti untuk dipelajari dan kemudian ditarik kesimpulannya, Sugiyono (2009:117). Adapun yang menjadi populasi dalam penelitian ini adalah seluruh siswa kelas $X$ SMA Negeri 2 Delima yang terdiri atas 4 kelas dengan jumlah 110 siswa yang terdiri atas 36 laki-laki dan 74 perempuan.

Sampel adalah sebagian dari populasi yang akan dijadikan objek penelitian, karena keterbatasan waktu maka penelitian tidak dilakukan untuk keseluruhan anggota populasi. Oleh karena itu, dilakukan pengambilan sampel sebanyak dua kelas secara purposive sampling, yaitu teknik pengambilan sampel/subjek dengan pertimbangan tertentu (Sugiyono, 2009:124). Sampel untuk penelitian ini adalah siswa kelas X MIPA2 sebagai kelas eksperimen dan kelas X MIPA1 sebagai kelas kontrol. Pemilihan sampel dengan pertimbangan kemampuan siswanya relatif sama sehingga tepat bila kedua kelas tersebut dilakukan penelitian. Gambaran kemampuan siswa diperoleh setelah berdiskusi dengan guru yang mengajar di kelas tersebut.

Teknik pengumpulan data yang digunakan dalam penelitian ini adalah dengan menggunakan tes. Tes terdiri dari tes awal (pretes) dan tes akhir (postes). Data yang diperoleh dari hasil penelitian ini berupa data tes hasil belajar. Data hasil tes meliputi data hasil tes kemampuan berpikir kritis siswa. Pengolahan data dilakukan dengan bantuan software statistik SPSS dan Microsoft Excell 2010.

Setelah secara keseluruhan data terkumpul, tahap berikutnya adalah tahap 
pengolahan data. Tahap ini penting karena pada tahap inilah hasil penelitian dirumuskan. Pengolahan data digunakan statistik yang sesuai sehingga akan memberikan informasi yang selaras dengan hal yang diteliti:

\section{HASIL DAN PEMBAHASAN}

Hasil penelitian ini, penulis peroleh dengan cara memberikan pretes dan postes pada kelas eksperimen dan kelas kontrol. Pretes diberikan sebelum pelaksanaan pembelajaran diajarkan, sedangkan postes diberikan setelah pelaksanaan pembelajaran materi Persamaan Kuadrat pada kelas eksperimen (X MIPA2) dan kelas kontrol (X MIPA1) selesai diajarkan. Pembelajaran pada kelas eksperimen diajarkan dengan menggunakan model Pembelajaran Group Investigation (GI), sedangkan kelas kontrol diajarkan dengan model selain model Pembelajaran Group Investigation (GI).

Berdasarkan hasil uji normalitas yang telah dilakukan didapat kesimpulan bahwa skor gain ternormalisasi kelas model pembelajaran Group Investigation (GI), dan kelas konvensional berdistribusi normal. Sedangkan untuk uji homogenitas menunjukkan bahwa varians skor gain ternormalisasi kemampuan berpikir kritis siswa kedua kelompok homogen. Sehingga untuk membuktikan bahwa skor gain ternormalisasi kemampuan berpikir kritis siswa siswa kelas model pembelajaran Group Investigation berbeda dengan kelas konvensional dilakukan uji perbedaan rataan skor gain ternormalisasi dengan menggunakan uji-t. Berdasarkan hasil uji bahwa kedua data memiliki varians yang sama. Hal ini ditunjukkan pada Uji Homogenitas Varian yang memberikan nilai signifikan $F=0,896>0,05$. Dengan demikian digunakan sig.(2-tailed) $=0,05$ untuk data yang memiliki varians yang sama (Equal variansces assumed).
Tabel 1.

Data Hasil Uji Perbedaan Rataan Skor Gain Ternormalisasi

\begin{tabular}{|c|r|c|c|}
\hline \multicolumn{3}{|c|}{$t$-test for Equality of Means } & \multirow{2}{*}{ Kesimpulan } \\
\hline $\mathrm{t}$ & $d f$ & Sig. (2-tailed) & \\
\hline 3,52 & 46 & 0,000 & $\mathrm{H}_{0}$ Ditolak \\
\hline
\end{tabular}

Tabel diatas diperoleh thitung $=3,52$ untuk $\alpha=0,05$ dengan $\mathrm{df}=46$, nilai ttabel $=$ 2,02, maka thitung berada di daerah penolakan $\mathrm{H} 0$, atau nilai signifikan $0,000<\alpha$ $=0,05$ sehingga $\mathrm{H} 0$ ditolak yang artinya terdapat perbedaan yang signifikan antara peningkatan kemampuan berpikir kritis siswa yang mendapat model pembelajaran Group Investigation Dengan demikian dapat disimpulkan bahwa peningkatan kemampuan berpikir kritis siswa yang diajarkan dengan model pembelajaran Group Investigation (GI) lebih baik dari pada kemampuan berpikir kritis siswa yang diajarkan dengan model konvensional.

Pembahasan yang dimaksudkan dalam tulisan ini adalah uraian atau kajian terhadap peningkatan kemampuan berpikir kritis siswa yang terdapat dalam penelitian ini dibandingkan dengan temuan penelitian sebelumnya yang bersumber dari berbagai literatur. Hasil penelitian ini diharapkan dapat memberi penjelasan mengenai efek dari penerapan model Pembelajaran Group Investigation (GI) terhadap peningkatan kemampuan berpikir kritis siswa. Rumusan masalah dalam penelitian ini yang berkaitan dengan perbedaan kemampuan berpikir kritis siswa antara siswa yang memperoleh pembelajaran dengan model Pembelajaran Group Investigation (GI) dan yang memperoleh pembelajaran dengan model pembelajaran konvensional. Hasil penelitian menyimpulkan bahwa peningkatan kemampuan berpikir kritis siswa yang diajarkan dengan model Pembelajaran Group 
Investigation (GI) lebih baik daripada peningkatan kemampuan berpikir kritis siswa yang diajarkan dengan model pembelajaran selain model Pembelajaran Group Investigation (GI). Kesimpulan yang didapat dalam penelitian ini sesuai dengan hasil penelitian yang dilakukan oleh Wicaksono, Sagita, dan Nugroho (2017) yang menyimpulkan bahwa kemampuan berpikir kritis siswa yang mendapatkan pembelajaran dengan menggunakan model pembelajaran GI lebih baik dibandingkan dengan siswa yang memperoleh pembelajaran dengan menerapkan Model Pembelajaran TPS.

Hasil penelitian ini juga didukung oleh Sadikin, Fahinu dan Ruslan (2016) yang menyimpulkan bahwa Kemampuan berpikir kritis matematik siswa yang diajar dengan model pembelajaran Group Investigation lebih tinggi dari siswa yang diajar dengan model pembelajaran konvensional baik ditinjau dari seluruh siswa, maupun pada setiap kategori self concept. Penelitian ini juga didukung oleh hasil penelitian yang dilakukan Purnamasari (2019) juga menyimpulkan bahwa kemampuan berpikir kritis siswa yang belajar dengan menggunakan model Group Investigasi (GI) lebih baik dari siswa yang menggunakan metode pembelajaran konvensional. Keberhasilan pembelajaran dengan penerapan model Pembelajaran Group Investigation (GI) dikarenakan siswa melibatkan kesadarannya tentang aktivitas kognitifnya sendiri atau segala sesuatu yang berhubungan dengan aktivitas kognitifnya dalam memecahkan masalah. Pembelajaran dengan metode group investigation menuntut melibatkan siswa sejak perencanaan, baik dalam menentukan topik maupun cara untuk mempelajari melalui investigasi, Wena (2013: 195). Oleh karena itu, model Pembelajaran Group Investigation (GI) peserta didik memiliki peranan penting dalam memecahkan masalah. Khususnya dalam mengatur dan mengontrol aktivitas kognitif peserta didik dalam memecahkan masalah matematika. Sehingga belajar dan berpikir yang dilakukan oleh siswa dalam memecahkan masalah matematika menjadi lebih efektif dan efisien.

\section{SIMPULAN}

Berdasarkan data yang diperoleh pada penelitian yang telah dilakukan di kelas $\mathrm{X}$ SMA Negeri 2 Delima dan dilakukan analisis data serta pengujian terhadap hipotesis penelitian diperoleh nilai rata-rata pretes kelas eksperimen 33,65, rata-rata postes 76,53 dan rata-rata $\mathrm{N}$-gain 0,66 . Sedangkan rata-rata pretes kelas kontrol 34,04, rata-rata postes 66,53 dan rata-rata $\mathrm{N}$-gain 0,50 .

Berdasarkan uji terhadap hipotesis penelitian diperoleh nilai sig. (1-tailed) $0,0005 \leq 0,05$, maka dapat diambil kesimpulan bahwa peningkatan kemampuan berpikir kritis siswa yang diajarkan dengan model pembelajaran Group Investigation (GI) lebih baik dari pada peningkatan kemampuan berpikir kritis siswa yang diajarkan dengan model pembelajaran selain model pembelajaran Group Investigation (GI).

\section{DAFTAR PUSTAKA}

Daryanto dan Rahardjo. (2012). Model Pembelajaran Inovatif. Yogyakarta: Gava Media.

Purnamasari (2019). Perbandingan Pembelajaran Dengan Strategi Group Investigation (GI) untuk Meningkatkan Kemampuan Berfikir Kritis Pada Pembelajaran Trigonometri di Kelas X Sman 1 Dukupuntang. Jurnal SJRME: Vol. 1 (1).

Rochaminah, S (2008). Pengaruh Pembelajaran Penemuan terhadap 
Jurnal Sosial Humaniora Sigli (JSH)

p ISSN : 2615-3688

$e$ ISSN : 2716-0270

http://journal.unigha.ac.id/index.php/JSH

Kemampuan Berfikir Kristis Matematis. Desertasi pada PPs UPI tidak dipublikasikan.

Sadikin, Fahinu dan Ruslan (2016). Pengaruh Penerapan Model Pembelajaran Group Investigation dan Self Concept Terhadap Kemampuan Berpikir Kritis Matematik Siswa SMA. Jurnal Pembelajaran Berpikir Matematika: Vol. 1 http://ojs.uho.ac.id/index.php/JPBM/ article/view/8146/pdf.

Setiawan. (2006). Model Pembelajaran Matematika dengan Pendekatan Investigasi. Yogyakarta: Depdinas PPPG Matematika.

Slavin. (2005). Cooperative Learning. Bandung: Nusa Media.

Sugiyono (2009). Metode Penelitian Pendidikan, Pendekatan Kuantitatif,
Kualitatif dan R \& D. Bandung : Alfabeta.

Sumarmo. (2011). Kemampuan dan Disposisi Berpikir Kritis dan Kreatif Matematik. Jurnal Pengajaran MIPA, 17(17): 17-22.

Trianto. (2009). Mendesain Model Pembelajaran Inovativ-Progresif. Jakarta: Kencana Prenada Media Group.

Wena. 2013. Strategi Pembelajaran Inovatif Kontemporer. Jakarta : Bumi Aksara.

Wicaksono, Sagita, dan Nugroho (2017). Model Pembelajaran Group Investigation (Gi) Dan Think Pair Share (TPS) Terhadap Kemampuan Berpikir Kritis. Jurnal Aksioma, Vol. 8 (2). e-ISSN 2579-7646. 